\title{
Low Wind Speed Technology Phase II: Design and Demonstration of On-Site Fabrication of Fluted-Steel Towers Using LITS-Form ${ }^{\mathrm{TM}}$ Process
}

\section{Native American Technologies Company}

Project Description: Transportation and erection of very large wind turbine towers has a major impact on the capital cost of megawatt-scale wind turbines and may impede the use of the taller wind turbine towers needed to take advantage of the increased wind shear at greater heights.

A new method of metal plate forming produces an innovative fluted tubular steel tower design at a significantly lower cost than conventional rolled steel tubular towers. The LITS-Form ${ }^{\mathrm{TM}}$ metal forming process applies heat to the surface of a flat metal plate. The application of high heat flux results in a significant thermal gradient, and, upon rapid cooling, causes thermal distortion to the plate. Sophisticated sensor and control technologies are used to control the resulting distortion to form metal plate into fluted tower sections conforming to CAD models. Because this forming process requires no external force, it does

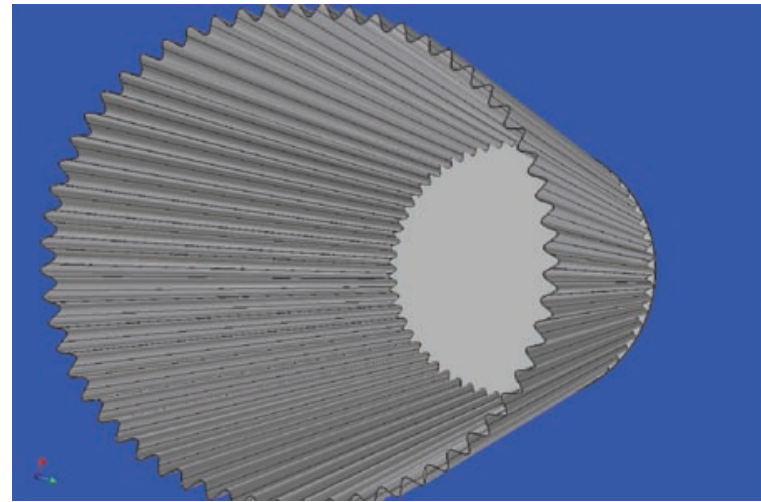

CAD rendering of a section (module) of the fluted tubular self-erecting tower. not require heavy foundations and can easily be dismantled and moved. Thus, fabrication of the tower components can be accomplished at the wind site. This means that the raw materials are delivered as flat steel plates, rather than fabricated components, resulting in a significant reduction in transportation costs. The added design and erection flexibility also provides for the possibility of self-erecting towers.

This project will complete a preliminary design of a tower and erection technique based on an existing commercial machine. Design will conclude with a demonstration of the technique at a reduced scale. Cost models will be developed based on the advanced forming and erection process.

$\begin{array}{ll}\text { Project Type: } & \text { Conceptual Design Study } \\ \text { Total Project Budget: } & \$ 195,460 \\ \text { Industry Cost Share: } & \$ 0 \\ \text { DOE Cost Share: } & \$ 195,460 \\ \text { Planned Project Duration: July 2004-July 2005 }\end{array}$

\section{Contacts:}

NREL/Sandia:

Scott Schreck, NREL

1617 Cole Blvd.

Golden, Colorado 80401

303-384-7102

scott_schreck@nrel.gov

\section{NA Tech :}

Dr. Jerry Jones, Native American Technologies Company

P.0. Box 39

Golden, C0 80402-0039

303-279-7942

Current Status:

JonesJE1@aol.com

Project Completed

\begin{abstract}
A Strong Portfolio for a Strong America • Energy efficiency and clean, renewable energy will mean a stronger economy, a cleaner environment, and greater energy independence for America. Working with a wide array of state, community, industry, and university partners, the U.S. Department of Energy's Office of Energy Efficiency and Renewable Energy invests in a diverse portfolio of energy technologies.
\end{abstract}

For more information contact EERE Information Center • 1-877-EERE-INF (1-877-337-3463) • www.eere.energy.gov

Produced for the U.S. Department of Energy by the National Renewable Energy Laboratory, a DOE national laboratory 